\title{
Spor Pazarlamasında Lisanslı Ürünlerin Tercihinde, Kulüp İmajı, Marka Efangelizmi, Takım Sadakati ve Takımla Özdeşleşme Değişkenlerinin Etkisi \\ (The Effect of Variables on Club Image, Brand Efangelism, Team Loyalty and Team Identification in the Choice of Licensed Products in Sports Marketing)
}

\author{
Şaban ALTIN iD a Leyla BEZGIN EDISŞ b İlknur TÜFEKÇI (iD c Behiye ALTIN iD d \\ a Yozgat Bozok Üniversitesi, Sosyal Bilimler Meslek Yüksekokulu, Yozgat, Türkiye. saban.altin@bozok.edu.tr \\ b Hitit Üniversitesi, Çorum, Türkiye. leyla.bezgin@hotmail.com \\ c Hitit Üniversitesi, Sungurlu Meslek Yüksekokulu, Çorum, Türkiye. ilknurtufekci@hitit.edu.tr \\ d Yozgat Bozok Üniversitesi, Şefaatli Meslek Yüksek Okulu, Yozgat, Türkiye. behiye.cicek@bozok.edu.tr
}

\begin{tabular}{|c|c|}
\hline MAKALE BİLGİSİ & ÖZET \\
\hline $\begin{array}{l}\text { Anahtar Kelimeler: } \\
\text { Kulüp İmajı } \\
\text { Efangelizm } \\
\text { Takımla Özdeşleşme }\end{array}$ & $\begin{array}{l}\text { Amaç - Spor endüstrisinin bir ürünü olan lisanslı ürünler tüm dünyada olduğu gibi Türkiye } \\
\text { pazarında da artış göstermiş, ekonomik bir araç olarak kullanılmaya başlanmış ve spor kulüplerinin } \\
\text { önemli bir gelir kalemi olmuştur. Yapılan bu araştırmada amaç, taraftarların lisanslı ürün satın alma } \\
\text { niyeti üzerinde kulüp imajı, marka efangelizmi ve takımla özdeşleşme düzeylerinin etkisini } \\
\text { incelemektedir. Bu etki belirlenirken takım sadakatinin aracllık rolüne de bakılmıştır. }\end{array}$ \\
\hline $\begin{array}{l}\text { Takım Sadakati } \\
\text { Satın Alma Niyeti }\end{array}$ & $\begin{array}{l}\text { Yöntem - Bu kapsamda Çorum ilinde yargısal örnekleme yöntemi ile belirlenmiş } 294 \text { kişiye online } \\
\text { anket uygulanmıştır. Anket sonucunda elde veriler tanımlayıcı ve tahminleyici istatistiksel } \\
\text { yöntemler ile analiz edilmiştir. Verilerin analizinde değişkenlerin yapısal geçerliliğine yönelik } \\
\text { doğrulayıcı faktör analizi ve araştırma hipotezlerinin test edilmesine yönelik yapisal eşitlik } \\
\text { modelinden yararlanılmıştır. }\end{array}$ \\
\hline $\begin{array}{l}2020 \\
\text { Revizyon Tarihi } 18 \text { Kasım } 2020\end{array}$ & $\begin{array}{l}\text { Bulgular - Analiz sonuçlarına göre, kulüp imajı, takımla özdeşleşme ve marka efangelizmi arasında } \\
\text { iliski gözlenmistir. Kulüp imajının takım sadakati, marka efangelizmi ve takımla özdeslesme }\end{array}$ \\
\hline Kabul Tarihi 15 Aralık 2020 & $\begin{array}{l}\text { üzerinde etkisi bulunurken, satın alma niyeti üzerinde etkisi bulunamamıştır. Taraftarların marka } \\
\text { efangelizm algılarının takım sadakatini ve satın alma niyetini etkilediği belirlenmiştir. Takımla } \\
\text { özdeşleşme düzeyinin takım sadakatini etkilemediği ancak satın alma niyetine etki ettiği } \\
\text { belirlenmiştir. Ayrıca takım sadakatinin, satın alma niyetini olumlu yönde ve doğrudan etkilediği } \\
\text { görülmektedir. Aracllık etkisine ilişkin sonuçlara bakıldığında ise, Taraftarların efangelizm } \\
\text { algılarının, satın alma niyeti değişkeni üzerindeki etkisinde takım sadakati değişkenin kısmi aracılık } \\
\text { etkisi olduğu belirlenmiştir. }\end{array}$ \\
\hline
\end{tabular}

Tartışma - Kulüp imajının artırılması durumunda taraftarların takım sadakatinin, marka efangelizm algılarının, takımla özdeşleşme düzeylerinin de artacağı, bu durumda taraftarların satın alma niyetinin de artacağı görülmektedir. Spor kulüpleri lisanslı ürünlerinin daha fazla talep görmesini istiyorsa, taraftarıyla özdeşleştirme düzeyini güçlendirerek taraftarı güçlü bir savunucusu (efangelizm) haline getirmesi gerekmektedir.

\begin{tabular}{ll}
\hline ARTICLE INFO & ABSTRACT \\
\hline Keywords: & $\begin{array}{l}\text { Purpose - Licensed products, which are a product of the sports industry, increased in the Turkish } \\
\text { market as well as all over the world, started to be used as an economic tool and turned into an } \\
\text { important income item for the sports clubs. The purpose of this study is to investigate the effect of } \\
\text { club image, brand eFANgelism and team identification levels on fans' intention to purchase licensed } \\
\text { eFANgelism }\end{array}$ \\
$\begin{array}{l}\text { products. The mediating role of team loyalty was also considered while determining this effect. } \\
\text { Team Loyalty } \\
\text { Purchase Intention }\end{array}$ & $\begin{array}{l}\text { Design/methodology/approach - In this context, an online questionnaire was applied to 294 people } \\
\text { determined by judicial sampling method in Çorum province. The data obtained as a result of the } \\
\text { survey were analyzed using descriptive and predictive statistical methods. Confirmatory factor } \\
\text { analysis for structural validity of variables and structural equation model for testing research } \\
\text { hypotheses were used in data analysis. }\end{array}$ \\
Received 14 October 2020 & $\begin{array}{l}\text { Findings - According to the results of the analysis, a relationship was observed between club image, } \\
\text { team identification and brand eFANgelism. While the image of the clubs had an effect on team } \\
\text { Revised 18 November 2020 }\end{array}$ \\
Accepted 15 December 2020 & \\
\hline
\end{tabular}

\section{Önerilen Atıf/ Suggested Citation}

Altın, Ş., Bezgin Ediş, L., Tüfekci, İ., A. Altın, B. (2020). Spor Pazarlamasında Lisanslı Ürünlerin Tercihinde, Kulüp İmajı, Marka Efangelizmi, Takım Sadakati ve Takımla Özdeşleşme Değişkenlerinin Etkisi, İşletme Araştırmaları Dergisi, 12 (4), $3759-3775$. 
It was determined that the brand eFANgelism perceptions of the fans affect their team loyalty and purchase intention. It was found out that the fans' level of team identification did not affect the team loyalty, but had an influence on the purchase intention. Furthermore, it is observed that team loyalty has a positive and direct effect on purchase intention. When the results regarding the mediation effect are considered, the mediating effect of team loyalty cannot be mentioned as the club image does not have a significant effect on the purchase intention of the fans. In addition to this, there is no mediation effect since the team identification level does not have a direct effect on team loyalty. It was determined that the variable of team loyalty had a partial mediating effect on the effect of fans' eFANgelism perceptions on the purchase intention variable.

Discussion - It is seen that if the club image is increased, the team loyalty of the fans, their brand efficacy perception and their level of identification with the team will also increase, and in this case, the purchase intention of the fans will increase. If sports clubs want their licensed products to be in greater demand, they must strengthen their level of identification with their fans and turn them into a strong advocate (effangelism).

\section{GİRIŞ}

Dünyada, spor kulüpleri tarafından satışa sunulan lisanslı spor ürünlerinden elde edilen gelirler, yıllık milyarlarca dolar perakende satışlara ulaşan kazançlı bir gelir kaynağı haline gelmektedir (Çiftyıldız, 2015: 223). Bu durum spor pazarlaması kavramının önemini artırmaktadır. Spor pazarlamasının kapsamında, spor ürünlerinin üretimi, fiyatlandırılması, dağıtımı ve tutundurması için yürütülen faaliyetlerin düzenlenmesi ve uygulanması süreçleri yer almaktadır (Pits vd., 1994: 80). Spor pazarlamasında üzerinde durulan iki önemli nokta sporun kendisinin ve spor ürünlerinin pazarlanmasıdır. Lisanslı ürünler ise spor pazarlamasında önemli bir yer edinmektedir. Lisanslı ürünler, taraftarların takımla ilişki kurmasına, favori takım veya oyuncuya karşı desteklerini ifade etmelerine ve özel bir spor etkinliğinin somut hatıraları olarak karşımıza çıkmaktadır. Lisanslı ürünler, günlük fonksiyonel özelliklere sahip olan ürünleri (Örneğin; Giyim, ev/ofis eşyaları ve aksesuarlar) güçlü ve duygusal bir ekip ruhunu ifade eden, özel tüketim özelliklerine sahip, göze çarpan ürünlere dönüştürmektedir (Papadimitriou ve Apostolopoulou, 2015). Aynı zamanda bireyler kendilerini bir takımın hayranı olarak sınıflandırmak için lisanslı ürünleri kullanabilmektedirler. Lisanslı ürünler, bireylerin özsaygısını arttırmak isteyebileceği bir araç olabilmektedir (Cialdini vd., 1967).

Dünya genelinde spor pazarında, pazar payı en yüksek ve en fazla kar getiren spor dalı futbol olarak bilinmektedir. Futbol kulüpleri taraftarlarıyla kulüp arasında psikolojik bir bağ kurarak, her bir taraftarın kulüp ile kişisel bağlılık oluşturmasını sağlamak ve bu durumu sürekli hale getirmek istemektedirler (Yüksekbilgili, 2018). Dolayısıyla kulüp imajı, marka efangelizmi ve takımla özdeşleşme kavramları, profesyonel spor kulüplerinin gelecekteki yönetimi için kritik öneme sahip olduğu düşünülmektedir.

Spor endüstrisinin bir ürünü olan lisanslı ürünler, tüm dünyada olduğu gibi Türkiye pazarında da artış göstermektedir. Ekonomik bir araç olarak kullanılmaya başlanılan ve spor kulüplerinin önemli bir gelir kalemi olan lisanslı spor ürünlerinin, taraftarlar tarafından tercih edilme nedenlerinin belirlenmesi gerekmektedir. Yapılan bu araştırmada amaç, taraftarların lisanslı ürün satın alma niyeti üzerinde kulüp imajı, marka efangelizm algıları ve takımla özdeşleşme düzeylerinin etkisini ve bu değişkenler arasındaki ilişkileri incelemektir. Değişkenler arasındaki ilişkiler incelenirken, takım sadakatinin aracılık rolüne de bakılmıştır.

\section{KAVRAMSAL ÇERÇEVE VE LITERATÜR TARAMASI}

\subsection{Spor Pazarlaması ve Lisanslı Spor Ürünleri}

Spor pazarlaması kavram olarak farklı şekiller de tanımlanabilmektedir. İlk olarak 1978 yılında Advertising Age isimli dergide yer alan bu kavram, genel pazarlama tanımına dayanarak spor ürünlerinin üretimi, fiyatlandırılması, dağıtımı ve tutundurması için yürütülen faaliyetlerin düzenlenmesi ve uygulanması süreçleri olarak tanımlanmaktadır (Pitts vd., 1994: 80). Spor pazarlamasında üzerinde durulan iki önemli nokta, sporun kendisinin ve spor ürünlerinin pazarlanmasıdır. Lisanslı ürünler ise spor pazarlamasında önemli bir yer edinmektedir. Lisanslı spor ürünü, kulüp taraftarlarına ya da kulüp sponsorlarına fayda sağlamak üzere tasarlanmış ürün ve hizmetin birleşimi şeklinde ifade edilmektedir (Shank, 2002: 257). Lisanslı spor ürünleri uygulaması spor takımları ve organizasyonlar için büyük önem arz etmektedir. Son 20 yılda, Nike, Adidas ve Under Armour gibi markalar, ürünlerinin seçkin sporcular arasındaki etkinliğini artırmak ve Y kuşağı taraftarları hedeflemek amacıyla üniversiteler arası atletizm sponsorluğuna önem vermişlerdir. 


\section{Ş. Altın - L. Bezgin Ediş - İ. Tüfekci - B. Altın 12/4 (2020) 3759-3775}

Ayrıca daha yüksek eğitim seviyesine sahip taraftarlar spor kıyafetlerine daha fazla para harcamaktadırlar (Jensen vd., 2015).

Lisanslı spor ürünleri, kulüpler ve organizasyonlar için önemli bir yere sahip olduğu bilinmektedir. Lisanslı spor ürünlerinde, takım logosunun yer almasının satın alma niyeti ve kalite algısına olan etkisinin incelendiği araştırmalarda taraftarların kendi takımlarına ait logolu ürünleri rakip takımın ürünlerine göre daha kaliteli algıladığı belirtilmektedir. Aynı çalışmada katılımcıların, lisanslı ürünleri lisanslı olmayan ürünlere göre daha fazla kaliteli olarak nitelendirdiği belirtilmektedir (Kwak vd., 2015:10). Lisanslı spor ürünleri, spor taraftarlarını diğer takım taraftarlarıyla ve en sevdikleri takımla ilişkilendirmede önemli bir araç olarak görülmektedir. Papadimitriou ve Apostolopoulou, (2015) tarafından yapılan bir araştırmaya göre sosyalleşme, bir grupla ilişki ve kişinin aidiyet ihtiyacı, lisanslı spor ürünlerinin tüketimini artırmaktadır. Ayhan vd., (2017)'nin üniversite öğrencileri üzerine yaptığı araştırmada, lisanslı ürünlerin tercihine etki eden beş motivasyon kaynağı önem sırasına göre; "takıma destek, takımla özdeşleşme, kullanım hazzı, sosyal cazibe ve alışveriş hazzı" şeklinde sıralanmaktadır. Çelik vd., (2019)'nin Göztepe Spor Kulübü taraftarlarının takımın lisanlı ürünlerini satın alma niyetlerinin ölçüldügü araştırmalarında, taraftarların giyim ürünlerini daha çok tercih ettiklerini ve lisanslı ürün tercih etme nedenlerinin ise takıma maddi ve manevi destek sağlamak olduğu sonucuna varıldığı belirtilmektedir (Çelik vd., 2019). Lisanslı ürün satın alma niyetinin planlı davranış teorisi çerçevesinde incelendiği başka bir araştırmada ise, davranışlara yönelik tutumların, sübjektif (öznel) normların ve algılanan davranışsal kontrollerin lisanslı ürünlerin satın alma niyetleri üzerinde olumlu etkileri olduğu belirtilmektedir (Katlav ve Öney, 2018).

\subsection{Spor Kulübü İmajı}

Spor kulüpleri, toplumun spor ihtiyacı ve beklentilerine yönelik çeşitli kurallar çerçevesinde kurulmuş, bünyesinde bulunan üyelerin sorumluluklarının olduğu, profesyonel ya da amatör spor dallariyla insanlara hizmet sunan, aynı zamanda bireylerin davranış şekillerini etki altına alarak spora yönelimlerini sağlayan, hukuki alt yapıya sahip kurumlar olarak tanımlanmaktadır (Fişek, 1985; Şahin, 2004; Yıldız, 2010). Günümüz koşullarında spor kulüpleri bir işletme gibi hareket etmekte, yapılarını işletmeler gibi oluşturmaktadır. Dolayısıyla spor kulüplerinin paydaşları, sponsorları, üyeleri veya tüm kamuoyu için etkili bir imaj oluşturabilmesi kulüpler açısından son derce önemli hale gelmektedir (Kargün vd., 2017). Sözlük anlamı itibariyle imaj; bir kişi, kuruluş veya ülkenin dışa yansıyan şekli ya da fikri ve zihni anlamda algılanma biçimi anlamına gelmekte ve bir dizi bilgilendirme sürecinin sonucunda örgüt adına ulaşılan imge olarak tanımlanabilmektedir (Çağlar, 2013:138). Kulüp imajı ise, belirli bir sosyal veya kültürel gruba ortak bir gerçeklik vizyonu oluşturulmasına yönelik faaliyetler şeklinde ifade edilmektedir (Bromberger vd., 1987; Laverie ve Arnett, 2000). Futbol kulüpleri üzerinde yapılan bir araştırmaya göre, etkili bir kulüp imajının bilet satışları ve taraftarların memnuniyet düzeyleri üzerinde olumlu etkilere sahip olduğu belirtilmektedir (Beccarini ve Ferrand, 2006). Başka bir araştırmaya göre spor kulüplerinin toplum yararına faaliyetlerde bulunmasının basın ve medya araçlarında sürekli yer almasının kurumsal imajı artırdığı belirtilmektedir (Kargün vd., 2017).

\subsection{Takıma Yönelik Marka Evangelizmi (Efangelizm)}

Olumlu bir ağızdan ağza iletişimin uzantısı olan marka efangelizmi, markaya yönelik olumlu düşünceler yaymak ve başkalarını marka ile etkileşime girmeye ikna etme çalışılması olarak tanımlanmaktadır. Efangelist taraftarların markaları konusunda tutkulu ve duygularını başkalarıyla paylaşma ihtiyacı hissettiği belirtilmektedir (Matzler vd., 2007). Takıma yönelik marka efangelizm kavramı ise ilk kez 2015 yılında Dwyer, Greenhalgh ve Le Crom tarafından kullanılmıştır. Fanatik kelimesinin kısaltması olan "fan" kelimesi efangelizm kelimesinin içine yerleştirilerek "efangelizm" kelimesi ortaya çıkmıştır (Yüksekbilgili, 2017). Efangelistler, bir spor takımının ürünlerini ve hizmetlerini materyalist olmayan bir yaklaşımla etrafına aktarır ve takımına adanmışlık hissi ile bağlı marka efangelisti gibi davranır. Gönüllü olarak oluşturulmuş takım efangelistleri, takımlarının ürünlerini tanıtması, satış görevlisi gibi ürünleri araştırması kulüpler için çok önemlidir. Çünkü spor kulüpleri tarafından sunulan hizmet ve ürünlerin tutundurma faaliyetlerinde efangelistler gönüllü ve aktif olarak görev almaktadır. Bu da spor kulübünün pazarlama araştırmalarına destek sağlamaktadır (Küçükibiş ve Yurtsızoğlu, 2019).

Efangelizm yeni bir kavram olarak çok az araştırmaya konu olmuştur. Literatürdeki araştırmalara baktığımızda efangelizmi anlamak için daha çok demografik değişkenler üzerinde durulduğu görülmektedir. 


\section{Ş. Altın - L. Bezgin Ediş - İ. Tüfekci - B. Altın 12/4 (2020) 3759-3775}

Yapılan araştırmalarda demografik değişkenlerdeki farklılıkların efangelizm düzeyini etkilediği belirtilmektedir (Yüksekbilgili 2018; Küçükibiş ve Yurtsızoğlu, 2019; Yaşar ve Turğut, 2019). Büyükakgül ve Engin (2017) yaptığı araştırmada sosyal kimlik algısının efangelizm üzerinde etkili olduğunu belirtmektedirler.

Yapraklı ve arkadaşları (2020) tarafından yapılan araştırmada marka güveni ve marka özdeşleşmesi düzeylerinin marka efangelizmi üzerindeki etkileri araştırılmıştır. Buna göre marka efangelizmi üzerinde marka güveni ve marka özdeşleşmesinin etkisinin olduğu belirtilmektedir. Ayrıca marka güvenin, marka özdeşleşmesi düzeyi üzerinde etkili olduğu belirtilmektedir. Yılmaz ve Aykaç (2018) araştırmalarında, marka imajı ile marka efangelizmi arasında anlamlı bir ilişkinin olduğu belirtilmektedir. Balıkçığlu ve Oflazoğlu (2015) tarafından yürütülen diğer bir araştırmada marka efangelizmi, benlik-marka imajı uyumu ve marka sadakati arasındaki ilişkiler incelenmiştir. Araştırma sonucunda marka efangelizmi, benlik-marka imajı uyumu ve marka sadakati arasında olumlu yönlü bir ilişki olduğu belirtilmektedir. Anggraini (2018) tarafından yapılan araştırmada, marka memnuniyeti, taraftar-marka kimliği, marka çıkıntısı, marka güveni ve fikir liderliğinin marka efangelizmi üzerinde olumlu etkiye sahip olduğu ifade edilmektedir. Doss ve Carstens (2014) ise, kişilik özelliklerinin marka efangelizmi kavramı ile ilgili olup olmadığı araştırılmıştır. Dışadönüklük, açıklık, vicdan, nevrotiklik ve uyumluluktan oluşan beş büyük kişilik özelliklerinden; marka efangelizmi önemli ölçüde dışadönüklük, açıklık ve nevrotiklik ile ilgili olduğu belirlenmiştir. Riorini ve Widayati, (2016)marka güveni, marka kimliği, marka katılımı ve marka bağlılığının marka efangelizmi üzerinde olumlu bir etkiye sahip olduğu belirtilmektedir.

\subsection{Takımla Özdeşleşme}

Takımla özdeşleşme, taraftarların tuttuğu takımın başarı ya da başarısızlıklarını kendi başarı ya da başarısızlığı olarak algılayarak (Ashforth ve Mael, 1989), genellikle kendisini takımının bir yansıması olarak görmesi hali olarak tanımlanmaktadır (Jung, 2012). Takımla özdeşleşme ayrıca kişinin tuttuğu takımla kurduğu psikolojik bağ olarak da ifade edilmektedir (Wann ve Branscombe, 1993).

Taraftarların özdeşleşme düzeylerinin düşük, orta veya yüksek olması duygusal, bilişsel ve davranışsal tepkilerinin farklı olmasına neden olmaktadır (Polat vd., 2019; Sutton vd., 1997). Özdeşleşme derecesi düşük olan taraftarların spor faaliyetlerinde daha çok eğlendikleri ve daha fazla haz aldıkları; orta derecede özdeşleşen taraftarlar, taraftarları oldukları kulübün amblemlerinin veya renklerini taşıyan kıyafetleri tercih ettiği belirtilmiştir. Takım özdeşleşmeleri yüksek olan taraflar kendilerini kulübe bağlı hissettiklerini ifade etmekte ve takımları için daha fazla zaman ve kaynak ayırdığı belirtilmektedir (Sutton vd., 1997; Shapiro vd., 2013). Bu taraftarlar stadyumlara gelir ve takımlarıyla ilgili ürünleri satın almak için para harcar (Oliver ve Bearden, 1983). Ayrıca takımları başarısız olsa da takıma ilişkin tutumları ve sadakatleri olumsuz yönde etkilenmemekte hatta diğer bireyleri de olumlu tutum sergilemeye ikna etmektedirler (Enginkaya ,2014).

Takımla özdeşleşme ile ilgili yapılan araştırmalara bakıldığında, taraftarların takımla özdeşleme düzeylerinin kulübünün etkinliklerine katılma isteklerini (Fisher ve Wakefield, 1998; Aycan vd., 2009), takımların ürünlerini satın alma (Gwınner ve Swanson, 2003; Harolle vd., 2010), lisanslı ürünlere yönelik alım yapma (Wann ve Branscombe, 1993), sponsorların ürünlerini satın alma niyetine (Madrigal, 2001; Gwınner ve Swanson, 2003) etki ettiği belirtilmektedir. Carlson vd.(2009), yaptı̆̆ 1 araştırmada marka kişiliğinin özdeşleşme üzerinde olumlu bir etkiye sahip olduğunu belirtmektedir.

Türkiye'de yapılan araştırmalara bakıldığında, Polat ve arkadaşlarının (2019) yaptığı araştırmada takımla özdeşleşme, takım imajı ve takım sadakati arasındaki ilişkiyi incelenmektedir. Araştırma sonucunda takımla özdeşleşme, sadakat ve imaj seviyelerinin birbirleri üzerinde önemli ve olumlu etkilerinin olduğu belirtilmektedir. Altınok ve diğerleri (2017),'nin yaptığı araştırmada, lise öğrencilerinin tuttukları takım ile takımla özdeşleşme düzeyi arasında cinsiyet, spora katılıma şekline, takımın taraftar birliğine üye olmasına, öğrencilerin maça gitme sıklıklarına ve taraftarlığıyla ilgili suç içeren olaylara karışma durumuna göre anlamlı farklılık olduğu belirtilmektedir. Torlak ve diğerleri (2014) tarafından yapılan araştırmada, taraftarların takımla özdeşleşme düzeyinin, lisanslı ürünleri satın alma niyeti üzerinde ve takımların lisanslı ürünlerine yönelik kalite algılamaları üzerinde olumlu yönlü anlamlı etkilerinin olduğunu belirtilmektedir. Diğer bir araştırmada, Enginkaya (2014), yaptığı araştırmada, taraftarların takımla özdeşleşme düzeyi, markaya ilişkin tutumları ve satın alma niyetleri arasındaki ilişkileri incelemektedir. Demirel ve arkadaşları (2007), farklı üniversitelerdeki öğrencilerle yaptıkları araştırmada, erkek ve kız üniversite öğrencilerinin özdeşleşme 


\section{Ş. Altın - L. Bezgin Ediş - İ. Tüfekci - B. Altın 12/4 (2020) 3759-3775}

düzeylerinde anlamlı farklılık olduğu belirtilmektedir. Ayrıca taraftar topluluklarına üye olan ve üye olmayan üniversite öğrencilerinin özdeşleşme düzeyleri arasında da anlamlı farklılık olduğu belirtilmektedir.

\subsection{Takım Sadakati}

Müşteri sadakati belirli bir markaya yönelik olumlu bir tutum ve tutarlı bir satın alma davranışı olarak ifade edilmektedir (Wilkie, 1994). Spor bağlamında ise takım sadakati, bir takıma yönelik tutarlı ve kalıcı olumlu davranış ve tutumlarla sonuçlanan, bir takımla psikolojik bağlantıyı temsil etmektedir (Funk ve James, 2001). Araştırmacılar tarafından, sadakat yapısının, hem tutumsal hem de davranışsal boyutları içermesi gerektiği belirtilmektedir (Bauer vd., 2008; Kaynak vd., 2008; Bee ve Havitz, 2010; Bodet ve Bernache-Assollant, 2011). Davranışsal sadakat, takıma yönelik gerçek satın alma davranışını ifade etmektedir (Stevens ve Rosenberger, 2012). Bir sezonda veya zaman içinde oyuna katılım sıklığı, takımı medya aracılığıyla takip etme düzenliliği ve harcanan para gibi unsurları içerebilmektedir (Bodet ve Bernache, 2011). Alternatif olarak tutum sadakati, bir kişinin takıma olan bağllı̆̆ 1 ve tutum tercihini içeren psikolojik süreçlerin bir fonksiyonu olarak ifade edilmektedir (Bauer vd., 2008; Kaynak vd., 2008).

Taraftar motivasyon faktörlerinin davranışsal sadakat üzerinde etkisinin incelendiği bir araştırmada, takımla özdeşleşmenin ve psikolojik bağlllığının davranışsal sadakat üzerinde olumlu bir etkisinin olduğu belirtilmektedir. Davranışsal sadakatin en etkili boyutunun ise, kulüp ürünlerine olan sadakatin olduğu ifade edilmektedir (Giray ve Girişken, 2015).

Yapılan bu araştırmada, marka efangelizm kavramı ve diğer değişkenler, farklı bir yönleriyle ele alınmıştır. Çoklu değişkenler arasındaki ilişkilerin incelendiği ve modellendiği araştırmanın, literatürde yar alan diğer araştırmalardan bu yönüyle farklı olduğu ve literatüre katkıda bulunacağı düşünülmektedir. Araştırmanın analiz yönteminde son dönemde sosyal bilimler alanında sıkça kullanılan yapısal eşitlik modellemesinin kullanılması ve ortaya konan araştırma modelinin literatüre katkı bulunacağı düşünülmektedir.

\section{ARAŞTIRMANIN YÖNTEMI}

\subsection{Araştırmanın Amacı, Yöntemi ve Modeli}

Yapılan bu araştırmada, taraftarların lisanslı ürün satın alma niyeti üzerinde, kulüp imajı, marka efangelizmi ve takımla özdeşleşme düzeylerinin etkisinin incelemesi amaçlanmaktadır. Bu etki belirlenirken, takım sadakatinin aracılık rolüne de bakılmıştır. Bu kapsamda Çorum ilinde ikamet eden 18-35 yaş arası taraftar gruplarına üye kişiler arasından yargısal örnekleme yöntemi ile belirlenmiş, 294 kişiye online anket uygulanmıştır. Yapısal eşitlik modellemesi (YEM) varsayımlarına göre örneklem büyüklügünün 150 ve üzerinde olması durumunda veriler analiz edilebilmektedir. Ancak YEM temelli araştırmalarda asgari örneklem büyüklüğünün, tahmin edilecek parametre sayısının en az 10 katı kadar ( $\left.\mathrm{N}>\mathrm{P}^{*} 10\right)$ olması tavsiye edilmektedir (Gürbüz, 2019: 30). Anket uygulaması 01.11.2019 ile 31.12.2019 tarihleri arasında yapılmıştır.

Yapılan araştırmada uygulanan anketler iki bölümden oluşmaktadır. Anketin ilk bölümü sosyo- demografik özelliklerinden ve tuttukları takımla ilgili sorular sorulmuştur. İkinci bölümde kulüp imajı, marka efangelizmi, takımla özdeşleşme, takım sadakati ve lisanslı ürün satın alma niyetini ölçmeye yönelik sorular sorulmuştur. Kulüp imajının ölçümünde Sönmez vd. (2016), takıma yönelik marka efangelizmi ölçümünde Matzler vd. (2007), takımla özdeşleşme de Günay ve Tiryaki (2003), takım sadakatinin ölçümünde Sumino ve Harada (2004), satın alma niyetinin ölçümünde Kwon ve diğerlerinin (2007) araştırmalarından yararlanılarak oluşturulmuştur.

Anket sonucunda elde veriler tanımlayıcı ve tahminleyici istatistiksel yöntemler ile analiz edilmiştir. Araştırmada yer alan verilerin analiz yönteminde tanımlayıcı istatistiksel yöntemlerden frekans dağılımları ve yüzdelik dilimlerine yer verilmiştir. Modelde yer almayan sosyo-demografik özellikler (yaş, cinsiyet,gelir, tutulan takım, en çok satın alınan ürün) tablolar yardımıyla açıklanmıştır. Tahminleyici istatistiksel yöntem olarak, yapısal eşitlik modellemesine (YEM) yer verilmiştir. Şekil 1'de yer alan model, literatürden elde edilen bulgulardan yararlanılarak oluşturulmuştur. Modelde yer alan değişkenler arasındaki varsayıma dayalı ilişkiler incelendiğinde, kulüplerin sahip olduğu kulüp imajının, taraftarların takım sadakatini ve satın alma niyetini doğrudan etkilediği varsayılmaktadır. Ayrıca kulüp imajı ile marka efangelizmi ve takımla özdeşleşme değişkenleri arasında ilişki olduğu varsayılmaktadır. 


\section{Ş. Altın - L. Bezgin Ediş - İ. Tüfekci - B. Altın 12/4 (2020) 3759-3775}

Bununla birlikte, marka efangelizminin, takım sadakati ve taraftarların satın alma niyetini doğrudan etkilerken, taraftarların takımla özdeşleşme düzeyleri arasında da ilişki olduğu varsayılmaktadır. Ayrıca taraftarların takımla özdeşleşme düzeylerinin, takım sadakatini ve satın alma düzeyini doğrudan etkilediği varsayılmaktadır. Modelde yer alan değişkenler arasındaki dolaylı etkilere bakıldığında ise,kulüp imajı, marka efangelizmi ve takımla özdeşleşmenin, taraftarların satın alma niyetine etkisinde takım sadakatinin aracılık rolüne sahip olduğu varsayılmaktadır.

Araştırmanın teorik modelinden ve literatürden elde edilen bulgulara dayanılarak oluşturulan hipotezler ise aşă̆ıdaki şekilde ifade edilmiştir.

H1: Kulüplerin sahip olduğu kulüp imajı, taraftarların takım sadakatini etkiler.

H2: Kulüplerin sahip olduğu kulüp imajı, taraftarların satın alma niyetini etkiler.

H3: Kulüplerin sahip olduğu kulüp imajı ile taraftarların marka efangelizm algısı arasında ilişki vardır.

H4: Kulüplerin sahip olduğu kulüp imajı ile taraftarların takımla özdeşleşme düzeyi arasında ilişki vardır.

H5: Taraftarların marka efangelizm algısı, takım sadakatini etkiler.

H6: Taraftarların marka efangelizm algısı, satın alma niyetini etkiler.

H7: Taraftarların marka efangelizm algısı ile takımla özdeşleşme düzeyi arasında ilişki vardır.

H8: Taraftarların takımla özdeşleşme düzeyi takım sadakatini etkiler.

H9: Taraftarların takımla özdeşleşme düzeyi satın alma niyetini etkiler.

H10: Taraftarların takım sadakati düzeyi, satın alma niyetini etkiler.

H11: Kulüplerin sahip olduğu kulüp imajının, taraftarların satın alma niyetine etkisinde, takım sadakatinin aracı değişken rolü vardır.

H12: Taraftarların marka efangelizm algısının satın alma niyetine etkisinde, takım sadakatinin aracı değişken rolü vardır.

H13: Taraftarların takımla özdeşleşme düzeyinin satın alma niyetine etkisinde, takım sadakatinin aracı değişken rolü vardır.

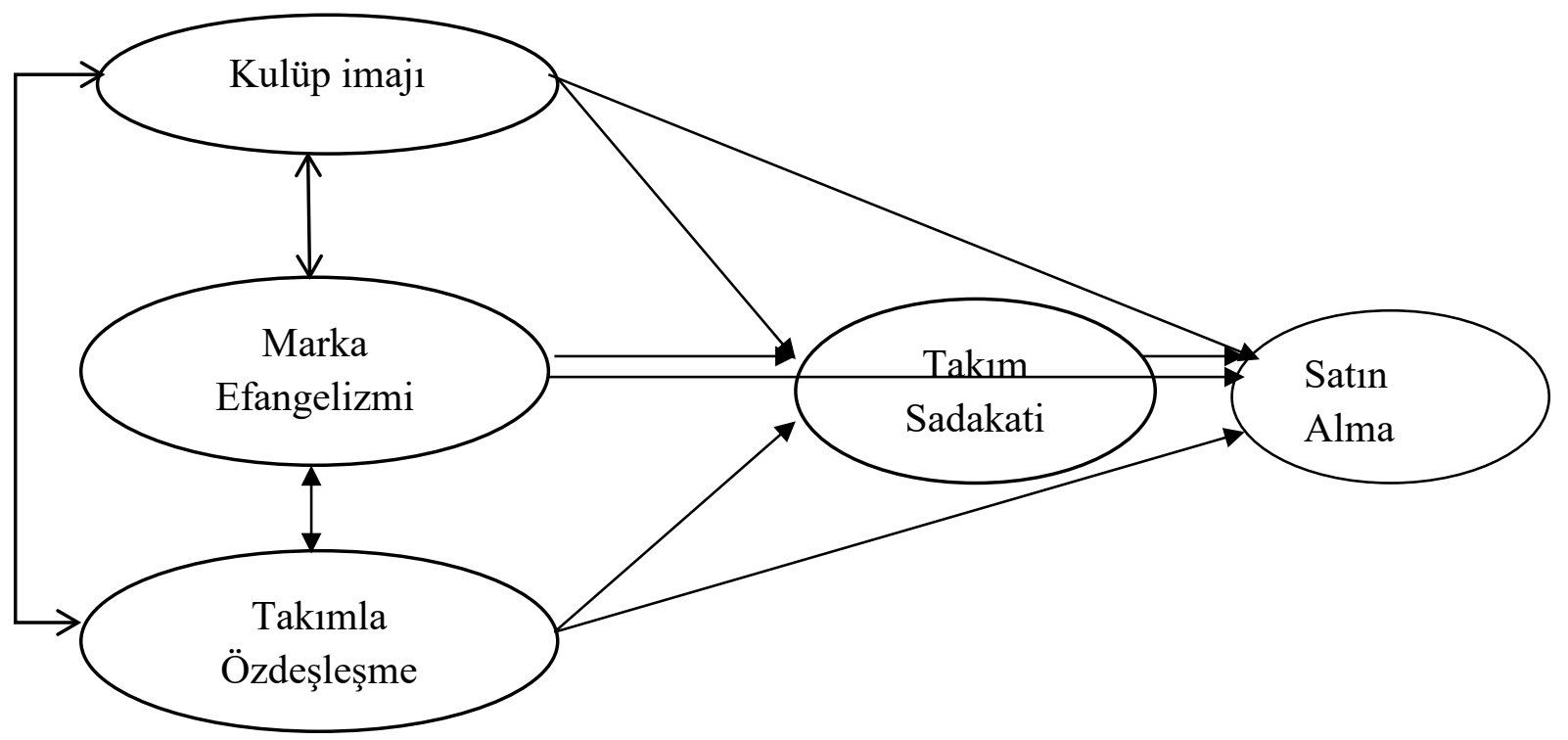

Şekil 1: Araştırmanın Teorik Modeli

\subsection{Verilerin Düzenlenmesi ve Analizi}

Araştırmadan elde edilen ham veriler analiz edilmeden önce istatiksel olarak analize uygunluğun olup olmadığının test edilmesi gerekmektedir. Analiz edilecek veri setinde aşırı uç değer ve kayıp değer olmamalıdır. Bu kayıp değerlerin olması bazı YEM analizi sonuçlarının elde edilmesini engelleyebilmektedir 


\section{Ş. Altın - L. Bezgin Ediş - İ. Tüfekci - B. Altın 12/4 (2020) 3759-3775}

(Gürbüz, 2019: 30). Bu kapsamda araştırmaya dahil edilen örneklem (taraftar) grubundan elde edilen verilerde kayıp değerlerin tespiti için "missing value-kayıp değer" analizi, uç değerlerin ve aşırı uç değerlerin tespiti için "uç değer (outlier)" analizlerine yer verilmiştir. Analiz sonucunda 17 adet verinin analize uygun olmadığ1 görülmüş ve analizden çıkarılmıştır. Kalan verilerin analiz edilebilmesi için bazı varsayımları sağlaması beklenmektedir. Normal dağılım bu varsayımlardan biridir. Yapısal eşitlik modellerinde verilerin normallik testi "Basıklık (kurtosis) ve Çarpıklık (skewness)" değerleri incelenerek elde edilmektedir (Tabachnick ve Fidell, 2012:79). Veriler toplanması amaciyla oluşturulan anket formunda yer alan ölçeklerin yeterli güvenilirliğe sahip olup olmadığını test etmek için, Cronbach Alfa değerlerine, geçerliliklerinin test edilmesi için doğrulayıcı faktör analizlerine yer verilmiştir.

\section{ARAŞTIRMANIN BULGULARI}

\subsection{Katılımcıların Sosyo-Demografik Özellikleri}

Araştırma katılımcıları olan 277 taraftara ait sosyo-demografik özelliklerine ilişkin veriler Tablo 1'de gösterilmektedir.

Tablo 1. Taraftarların Sosyo-Demografik Özelliklere Ait Bulgular

\begin{tabular}{|c|c|c|c|c|c|}
\hline Yaş & Sayı & $\%$ & $\begin{array}{l}\text { Takımınızın } \\
\text { lisanslı ürünlerini } \\
\text { hiç satın aldınız mı }\end{array}$ & Sayı & $\%$ \\
\hline $18-29$ & 169 & 61,1 & Evet & 208 & 75,1 \\
\hline $30-39$ & 68 & 24,5 & Hayır & 69 & 24,9 \\
\hline $40-49$ & 33 & 11,9 & Cinsiyet & Say1 & $\%$ \\
\hline 50 ve üstü & 7 & 2.5 & Erkek & 161 & 58,1 \\
\hline Aylık gelir & Say1 & $\%$ & Kadın & 116 & 41,9 \\
\hline $0-1603 T L$ & 109 & 39,4 & $\begin{array}{l}\text { En Çok Satın } \\
\text { Aldığınız Ürün }\end{array}$ & Sayı & $\%$ \\
\hline 1604-3000TL & 61 & 22,0 & Takım Forması & 161 & 58,1 \\
\hline 3001-4500TL & 46 & 16,6 & Bayrak/ Afiş & 7 & 2,5 \\
\hline 4501ve üzeri & 61 & 22,0 & Forma Dişı Kiyafet & 14 & 5,1 \\
\hline Hangi takımı tutuyorsunuz & Sayı & $\%$ & Çocuk Ürünleri & 7 & 2,5 \\
\hline Beşiktaş & 69 & 24,9 & Aksesuar & 14 & 5,1 \\
\hline Fenerbahçe & 74 & 26,7 & Hatıralık & 1 & 0,4 \\
\hline Galatasaray & 86 & 31,1 & Diğer & 72 & 26,3 \\
\hline Trabzonspor & 31 & 11,2 & & & \\
\hline Diğer & 17 & 6,1 & & & \\
\hline \multicolumn{6}{|l|}{$(\mathrm{N}: 277)$} \\
\hline
\end{tabular}

Tabloda yer alan bilgilere göre araştırmada yer alan 277 taraftarın, \% 41,9' u kadın, \% 58,1' i erkektir. Taraftarların \% 61,1' i 18-29 yaş aralığında ve \% 24,5' i 30-39 yaş aralığındadır. Aylık gelir gruplarına göre dağılımlarına bakıldığında ise \% 39,4' ünün 1604-3000 TL aralığında, \% 16,6' sının ise 3000-4500 TL aralığında olduğu görülmektedir. Taraftarların hangi takımı tutuyorsunuz sonuçlarına ilişkin bulgulara göre ise, \% 24,9 'ü Beşiktaş, \% 26,7' sinin Fenerbahçe, \%31,0 ise Galatasaray, \% 11,2' si Trabzonspor ve \%6,1' diğer takımlardan oluşmaktadır. Takımınızın lisanslı ürünlerini hiç satın aldınız mı? sorusuna taraftarların \% 75,1' i evet, \% 24,9' u hayır yanıtını vermiştir. Taraftarlara en çok satın aldığınız ürün hangisidir? Diye sorduğumuzda \%58,1' i Takım Forması, \%2,5' i bayrak/ afiş, \% 5,' i forma dışı kıyafet, \% 2,5' i çocuk ürünleri, \% 5,1' i aksesuar, \% 0,4 hatıralık,\% 26,3' ü diğer ürünleri satın aldığını belirtmektedirler.

\subsection{Verilerin Dă̆ılımına ve Güvenilirlik Analizlerine Ait Bulgular}

Katılımcılardan elde edilen verilerin dağılımına ilişkin analiz sonuçlarına göre, veri setinin normal dağılıma sahip olduğu görülmektedir. Veri setinin normallik testlerine ilişkin literatürde yer alan bulgulara bulgulara göre "Basıklık (kurtosis) ve Çarpıklık (skewness)" değerlerine bakılarak normallik ölçülebilmektedir 


\section{Ş. Altın - L. Bezgin Ediş - İ. Tüfekci - B. Altın 12/4 (2020) 3759-3775}

(Tabachnickve Fidell, 2012: 79; Gürbüz, 2019: 30). Bayram'a (2010:49) Literatüre göre, bu değerlerin , +/- 1,0 veya $+/-1,5$ aralığında olması durumunda normal dağılıma sahip olduğu kabul edilirken (Bayram, 2010:49), Hair ve arkadaşları ise sig $<0,01$ olduğunda bu değerlerin $+/-2,58$ olması veya sig $<0,05$ ise $+/-1,96$ aralığında olması gerektiğini belirtmektedirler (Hair vd., 2009:72). Kalaycı'ya göre ise bu değerlerin +/-3(Gürbüz, 2019:30) veya +/- 2 aralığında olması normal dağılım için yeterli görülmektedir (Kalaycı, 2009:6).

Tablo 2. Araştırma Verilerinin Dağılımına ve Güvenilirliğine Ait Bulgular

\begin{tabular}{|c|c|c|c|c|c|c|c|c|c|}
\hline \multirow[b]{2}{*}{ Ölçekler } & \multirow[b]{2}{*}{ İfadeler } & \multirow{2}{*}{\begin{tabular}{|l}
$\mathrm{N}$ \\
Istatistik
\end{tabular}} & \multicolumn{2}{|c|}{\begin{tabular}{|l|l|} 
Ortalama Sapma \\
\end{tabular}} & \multicolumn{2}{|l|}{ Çarpıklık } & \multicolumn{2}{|l|}{ Basıklık } & \multirow[b]{2}{*}{$\begin{array}{l}\text { Cronbach } \\
\text { Alfa }\end{array}$} \\
\hline & & & İstatistik & İstatistik & İstatistik & $\left\{\begin{array}{l}\text { Std. } \\
\text { Hata }\end{array}\right.$ & İstatistik & $\begin{array}{l}\text { Std. } \\
\text { Hata }\end{array}$ & \\
\hline \multirow{12}{*}{  } & efangelizm1 & 277 & 3,7184 & 1,29385 &,- 838 & 146 &,- 446 & 292 & \multirow{12}{*}{,928 } \\
\hline & efangelizm2 & 277 & 3,4513 & 1,38652 &,- 494 & 146 & $-1,095$ & ,292 & \\
\hline & efangelizm3 & 277 & 2,7040 & 1,31563 & 195 & 146 & $-1,213$ & 292 & \\
\hline & efangelizm4 & 277 & 2,9097 & 1,45057 & 065 & 146 & $-1,419$ & 292 & \\
\hline & efangelizm5 & 277 & 3,0361 & 1,45418 &,- 077 & 146 & $-1,452$ & 292 & \\
\hline & efangelizm6 & 277 & 2,6715 & 1,32848 & 303 & 146 & $-1,152$ & 292 & \\
\hline & efangelizm7 & 277 & 3,2671 & 1,51828 &,- 304 & 146 & $-1,438$ & 292 & \\
\hline & efangelizm8 & 277 & 3,1264 & 1,38388 &,- 278 & 146 & $-1,256$ & 292 & \\
\hline & efangelizm9 & 277 & 2,7798 & 1,33727 & 125 & 146 & $-1,265$ & 292 & \\
\hline & efangelizm10 & 277 & 2,9892 & 1,35262 &,- 113 & 146 & $-1,297$ & 292 & \\
\hline & efangelizm11 & 277 & 3,0144 & 1,37780 &,- 068 & 146 & $-1,321$ & 292 & \\
\hline & efangelizm12 & 277 & 3,3430 & 1,37843 &,- 501 & 146 & $-1,084$ & 292 & \\
\hline \multirow{6}{*}{ 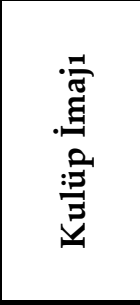 } & imaj1 & 277 & 3,9639 & 1,13833 & $-1,176$ & 146 & 775 & 292 & \multirow{6}{*}{,910 } \\
\hline & imaj2 & 277 & 3,9134 & 1,11952 &,- 952 & 146 & 280 & 292 & \\
\hline & imaj3 & 277 & 3,8592 & 1,08932 &,- 954 & 146 & 427 & 292 & \\
\hline & imaj4 & 277 & 3,5848 & 1,23250 &,- 595 & 146 &,- 532 & 292 & \\
\hline & imaj5 & 277 & 3,8484 & 1,08953 &,- 830 & 146 & 127 & 292 & \\
\hline & imaj6 & 277 & 3,4946 & 1,13131 &,- 501 & 146 &,- 259 & 292 & \\
\hline \multirow{3}{*}{ 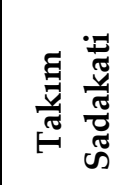 } & sadakat1 & 277 & 3,8556 & 1,23392 &,- 981 & 146 &,- 027 & 292 & \multirow{3}{*}{,895 } \\
\hline & sadakat2 & 277 & 3,6498 & 1,28964 &,- 651 & 146 &,- 657 & 292 & \\
\hline & sadakat3 & 277 & 4,1588 & 1,17802 & $-1,598$ & 146 & 1,710 & 292 & \\
\hline \multirow{4}{*}{ 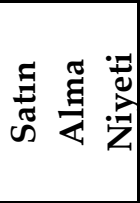 } & satınalma1 & 277 & 3,6715 & 1,29534 &,- 710 & 146 &,- 594 & 292 & \multirow{4}{*}{,944 } \\
\hline & satınalma2 & 277 & 3,6462 & 1,24139 & -699 & 146 &,- 448 & 292 & \\
\hline & satınalma3 & 277 & 3,7401 & 1,21775 &,- 812 & 146 &,- 287 & 292 & \\
\hline & satınalma4 & 277 & 3,6606 & 1,30787 & -693 & 146 &,- 672 & 292 & \\
\hline \multirow{7}{*}{ 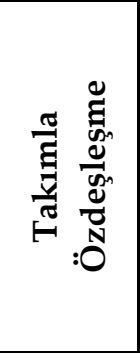 } & özdesleme1 & 277 & 4,2255 & 1,22773 & $-1,622$ & 146 & 1,524 & 292 & \multirow{7}{*}{,926 } \\
\hline & özdesleme2 & 277 & 3,8109 & 1,31624 &,- 866 & 146 &,- 383 & 292 & \\
\hline & özdesleme3 & 277 & 3,6436 & 1,39497 &,- 674 & 146 &,- 796 & 292 & \\
\hline & özdesleme4 & 277 & 3,6255 & 1,44014 &,- 642 & 146 &,- 959 & 292 & \\
\hline & özdesleme5 & 277 & 3,8582 & 1,41865 &,- 943 & 146 &,- 507 & 292 & \\
\hline & özdesleme6 & 277 & 3,1564 & 1,59514 &,- 194 & 146 & $-1,498$ & 292 & \\
\hline & özdesleme7 & 277 & 3,0364 & 1,44166 &,- 071 & 146 & $-1,272$ & 292 & \\
\hline
\end{tabular}

Tablo 2 de yer alan tanımlayıcı istatistik ve güvenilirlik sonuçlarına göre örneklemden elde edilen "Basıklık (kurtosis) ve Çarpıklık (skewness)" değerlerine ait analiz sonuçlarının +/-2 aralığında olduğu ve değişkenlere ait değerlerin normal dağılım gösterdiği gözlenmiştir. Yapılan bu araştırmadaki her bir ölçeğin güvenilirlik analizlerine göre güvenilirlik değerlerinin (Cronbach Alfa değerinin) 0,80- 1,00'ın arasında olduğu gözlenmiştir. Bu sonuçlara göre ölçeklerin oldukça güvenilir ölçekler olduğu söylenebilir (Kalayc1, 405: 2009). 


\subsection{Geçerlilik Analizlerine Ait Bulgular}

Araştırma ölçeklerinin geçerliliği AMOS 21.0 programı yardımıyla DFA ile analizleri ile test edilmiştir. Her bir değişkenin faktör yapılarının istatistikselanlamlı olduğu doğrulanmıştır. Faktör yapılarının analizinde tahmin yöntemimaksimum olabilirlik olarak belirlenmiştir. YEM'de bu yöntem faktör yapılarının dağılımlarının doğrulanması ve (Hair vd., 2009: 636; Schumacker ve Lomax, 2010: 85; Bayram, 2010:51) araştırma modeline ait uyum iyiliği değerlerinin en iyi sonuçlar vermesi açısından istenilen bir durumdur. Elde edilen tüm veriler ile ölçüm modelleri arasındaki ilişkilere ait birinci düzey tek faktörlü DFA ölçüm modelleri test edilmiştir.

Tablo 3. Ölçeklerin Doğrulayıcı Faktör Analizi Bulguları

\begin{tabular}{|l|l|l|l|l|l|l|l|l|}
\hline Ölçek / Model & $\mathbf{P}$ & $\Delta \chi^{2} /$ df & RMSEA & CFI & NFI & GFI & AGFI & RMR \\
\hline $\begin{array}{l}\text { Marka } \\
\text { Efangelizm }\end{array}$ &, 000 & 4,401 & 0,111 &, 918 &, 835 &, 882 &, 820 & 0,124 \\
\hline $\begin{array}{l}\text { Kulüp } \\
\text { İmajı }\end{array}$ &, 041 & 2,318 & 0,690 &, 994 &, 990 &, 986 &, 942 & 0,028 \\
\hline $\begin{array}{l}\text { Takım } \\
\text { sadakati }\end{array}$ &, 000 & 0,000 & 0,779 & 1,000 & 1,000 & 1,000 & 1,000 & 0,000 \\
\hline $\begin{array}{l}\text { Satın alma } \\
\text { Niyeti }\end{array}$ &, 047 & 0,051 & 0,000 & 1,000 & 1,000 &, 999 &, 991 & 0,003 \\
\hline Takımla Özdeşleşme & 0,002 & 2,548 & 0,075 &, 988 &, 981 &, 969 &, 928 & 0,040 \\
\hline
\end{tabular}

Not: İstatistiksel anlamlllk düzeyi $P<0,05^{\prime}$ tir

Araştırmaya ait verilerinin birinci düzey tek faktörlü ölçüm modellerine ait değerlerinin yer aldığı Tablo 3'te yer alan bulgular literatüre göre, $\Delta \chi^{2} / \mathrm{df}$ değeri 0 ile 5 aralığında değer aldığında anlamlıdır. Bu değer YEM'de ölçüm modeli ile verilerin uyum sağladığını gösteren en temel değerdir (Şimşek, 2007: 14; Hair vd., 2009: 641; Schumacker ve Lomax, 2010: 85). Ölçeklerden elde edilen verilerin doğrulanması için yapılan birinci düzey tek faktörlü ve ikinci düzey çok faktörlü doğrulayıcı faktör analizinden (DFA) elde edilen sonuçlar, verilerin ölçüm modelleri tarafından doğrulandığı göstermektedir. Ölçüm modellerinden elde edilen değerlere göre gerekli uyum iyileştirmeleri yapılmış ve standardize edilmiş faktör yükü 0,70' den az olan (Hair vd., 2009: 679) ifadeler ve "p değeri" 0,05'ten büyük olan ifadeler, ölçekten çıkarılarak, program tarafından önerilen hata terimleri arasında kovaryanslar oluşturulmuştur (Bayram, 2010: 57; Meydan \& Şeşen, 2015:74-75). 


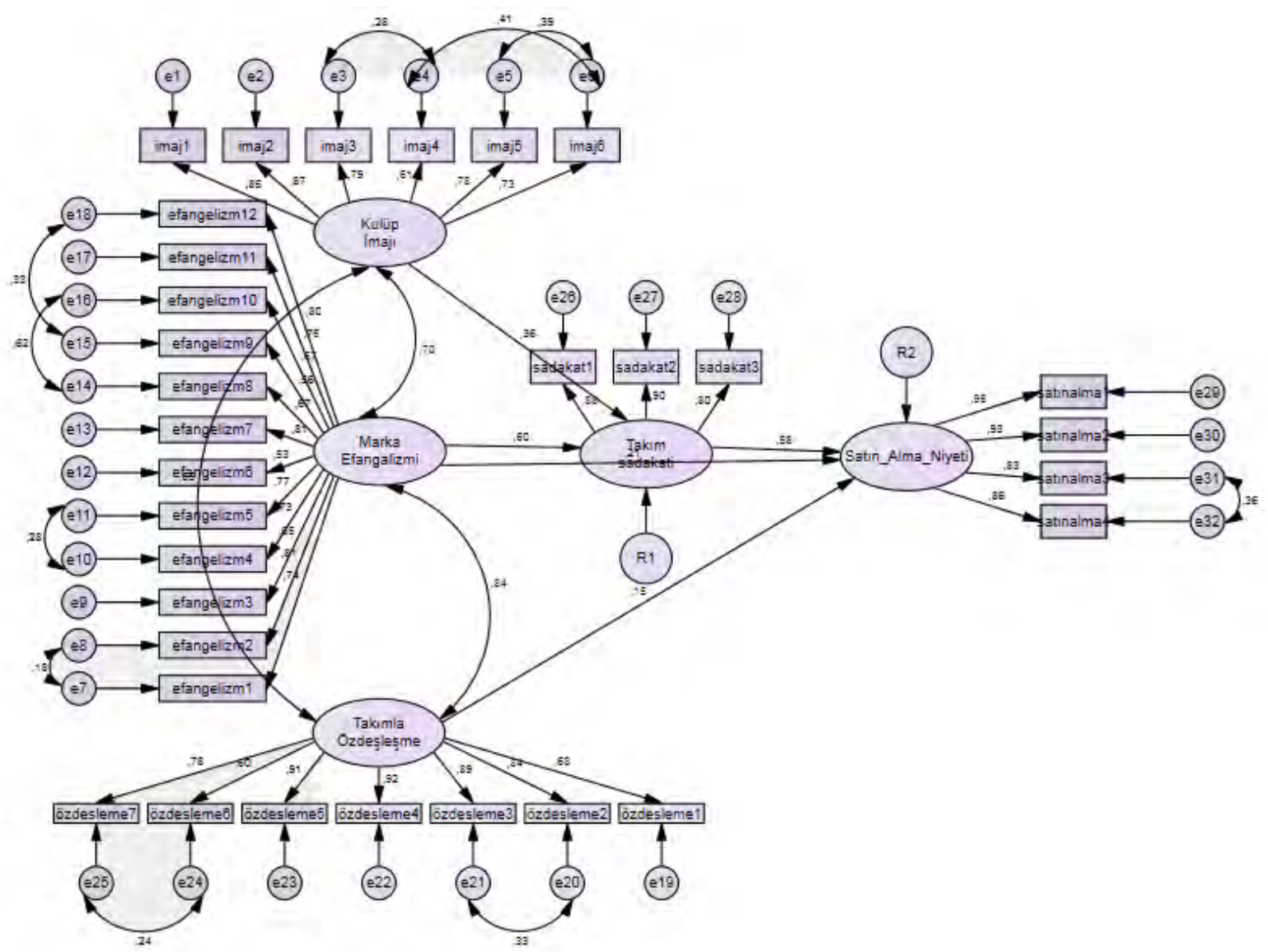

\section{Şekil 2. Kulüp İmajı, Marka Efangelizm Takımla Özdeşleme Düzeylerinin Taraftarlarının Satın Alma Niyetine Etkisinde Takım Sadakatinin Aracılık Etkisine Ait Yapısal Eşitlik Modeli}

Şekil 2' deki araştırma modeli literatürdeki araştırmalar sonucunda elde edilen bulgulara dayalı olarak, AMOS 21 programı kullanılarak oluşturulmuştur. Şekil 2 programa ait bir görseldir. Araştırma modelinde yer alan kulüp imajı, marka efangelizmi ve takımla özdeşleşme değişkenleri, etkileyen değişkenler iken, satın alma niyeti değişkeni etkilenen değişken olarak tanımlanmıştır. Takım sadakati değişkeni ise hem etkileyen değişken hem de etkilenen değişken olduğu için aracı değişken olarak model de yer almaktadır. Araştırma modelinin anlamlılığı ve kabul edilebilir olduğuna dair değerler Tablo $4^{\prime}$ de gösterilmiştir. Modelin değişkenleri arasındaki ilişkilere ait istatistiki bulgular ise, Tablo $5^{\prime}$ de yer almaktadır.

Tablo 4: Araştırma Modelinin Uyum Değerleri

\begin{tabular}{|l|l|l|l|l|l|l|l|l|l|}
\hline Ölçüm & $\Delta \chi^{2}$ & $\mathbf{P}$ & $\mathbf{d f}$ & $\Delta \chi^{2} /$ df & RMSEA & CFI & NFI & GFI & RMR \\
\hline Model & 972,474 &, 000 & 446 & 2,180 & 0,065 & 0,932 & 0,883 & 0,873 & 0,085 \\
\hline
\end{tabular}

Tablo 4'de ki araştırma modelinin uyum değerlerine bakıldığında, değerlerin kabul edilebilir düzeylerde olduğu gözlenmiştir. Tablodaki Ki-kare değeri/serbestlik derecesi $\left(\Delta \chi^{2} / \mathrm{df}=2,180\right)$, Yapısal eşitlik modellerinde, araştırma modelinin kabulünde kullanılan genel uyum iyiliği değerlenmesinde yararlanılan en temel değer olarak kabul edilmektedir (Şimşek, 2007: 14; Hair vd., 2009: 641; Schumacker ve Lomax, 2010: 85). Bu değerin 1-3 aralığında mükemmel uyum 3-5 aralığında ise kabul edilebilir uyum olduğu belirtilmektedir (Şimşek, 2007:14). Bazı araştırmacılara göre bu değerlerle birlikte RMSEA, GFI, CFI, NFI değerlerin de oldukça önemli olduğu belirtilmektedir. RMSEA değeri 0,05 ile 0,08 arası kabul edilebilir uyuma, RMR 0,06 ile 0,08 arası iyi uyuma karşlık gelirken, CFI, NFI, GFI değerleri 0,90 ile 0,95 arası kabul edilebilir uyum değerleridir (Meydan ve Şeşen, 2015: 37, Gürbüz, 2019: 34). 


\section{Ş. Altın - L. Bezgin Ediş - İ. Tüfekci - B. Altın 12/4 (2020) 3759-3775}

Tablo 5. Araştırma Modelindeki Değişkenler Arası İlişkiler

\begin{tabular}{|c|c|c|c|c|c|}
\hline \multicolumn{3}{|c|}{ Değişkenler Arası İlişkiler } & \multirow{2}{*}{$\begin{array}{l}\text { Standardize } \\
\text { Edilmiş } \beta \\
, 361\end{array}$} & \multirow{2}{*}{$\frac{\mathbf{P}}{* * *}$} & \multirow{2}{*}{$\begin{array}{l}\begin{array}{l}\text { Hipotez } \\
\text { Kabul/Red }\end{array} \\
\text { H1 Kabul }\end{array}$} \\
\hline Takım_sadakati & $<---$ & Kulüp_İmaj1 & & & \\
\hline Satın_Alma_Niyeti & $<---$ & Kulüp_İmaj1 & 072 & ,252 & H2 Red \\
\hline Takım_sadakati & $<---$ & Marka_Efangalizmi & 603 & $* * *$ & H5 Kabul \\
\hline Satın_Alma_Niyeti & $<---$ & Takımla_Özdeşleşme & ,146 & ,041 & H9 Kabul \\
\hline Takım_Sadakati & $<---$ & Takımla_Özdeşleşme & ,093 & ,227 & H8 Red \\
\hline Satın_Alma_Niyeti & $<---$ & Takım_sadakati & ,580 & $* * *$ & H10 Kabul \\
\hline Satın_Alma_Niyeti & $<---$ & Marka_Efangalizmi & ,213 & ,042 & H6 Kabul \\
\hline Kulüp_İmajı & $<-->$ & Marka_Efangalizmi & 703 & $* * *$ & H3 Kabul \\
\hline Marka_Efangalizmi & $<-->$ & Takımla_Özdeşleşme &, 839 & $* * *$ & H7 Kabul \\
\hline Kulüp_İmaj1 & $<-->$ & Takımla_Özdeşleşme & 649 & $* * *$ & H4 Kabul \\
\hline
\end{tabular}

İstatistiksel anlamlılık düzeyi $=\mathrm{p}<0,05^{\prime}$ tir.

Tablo 5'de araştırma modeline ait değişkenler arasındaki ilişkilerin standardize edilmiş regresyon katsayıları gösterilmektedir. Elde edilen bulgulara göre değişkenler arası ilişkilerde $p<005$ olan değerler istatistiksel olarak anlamlıdır. Bu durumda, kulüplerin sahip olduğu kulüp imajının, taraftarların takım sadakati düzeyini doğrudan olumlu yönde etkilediği belirlenmiştir. Bu etki $(\beta=, 361$ ve $p<0,005)$ değerlerine göre istatistiki olarak anlamlı ve kabul edilebilir bir değerler olduğu için $\mathrm{H} 1$ hipotezi kabul edilmektedir. Ayrıca kulüplerin sahip olduğu kulüp imajının, taraftarların satın alma niyetini doğrudan olumlu yönde etkilediği belirlenmiştir. Bu etki $(\beta=, 072$ ve $p<0,252)$ değerlerine göre istatistiki olarak anlamlı ve kabul edilebilir değerler olmadığı için $\mathrm{H} 2$ hipotezi red edilmektedir. Aynı zamanda taraftarların marka efangelizm algıları ile kulüplerin sahip olduğu kulüp imajları arasında olumlu yönde güçlü bir ilişki olduğu gözlenmiştir. Bu ilişki $(\mathrm{r}=, 703$ ve $\mathrm{p}<0,000)$ değerlerine göre istatistiki olarak anlamlı ve kabul edilebilir bir değer olduğu için H3 hipotezi kabul edilmektedir.

Taraftarların takımla özdeşleşme düzeyleri ile kulüplerin sahip olduğu kulüp imajları arasında olumlu yönde güçlü ilişki olduğu gözlenmiştir. Bu ilişki $(R=, 649$ ve $p<0,000)$, değerlerine göre istatistiki olarak anlamlı ve kabul edilebilir değerler olduğu için H4 hipotezi kabul edilmektedir. Aynı zamanda taraftarların marka efangelizm algılarının, takım sadakati düzeylerini doğrudan olumlu yönde etkilediği belirlenmiştir. Bu etki $(\beta=, 603$ ve $p<0,000)$ değerlerine göre istatistiki olarak anlamlı ve kabul edilebilir değerler olduğu için H5 hipotezi kabul edilmektedir.

Taraftarların marka efangelizm algılarının, satın alma niyeti düzeylerini doğrudan olumlu yönde etkilediği belirlenmiştir. Bu etki $(\beta=, 213$ ve $p<0,042)$ değerlerine göre istatistiki olarak anlamlı ve kabul edilebilir değerler olduğu için H6 hipotezi kabul edilmektedir. Taraftarların marka efangelizm algıları ile taraftarların sahip olduğu takımla özdeşleme düzeyleri arasında olumlu yönde güçlü bir ilişki olduğu gözlenmiştir. Bu ilişki $(r=, 839$ ve $p<0,000)$ değerlerine göre istatistiki olarak anlamlı ve kabul edilebilir bir değer olduğu için H7 hipotezi kabul edilmektedir.

Taraftarların takımla özdeşleşme düzeylerinin, takım sadakati düzeyini doğrudan olumlu yönde etkilediği belirlenmiştir. Bu etki $(\beta=, 093$ ve $p<0,227)$ değerlerine göre istatistiki olarak anlamlı ve kabul edilebilir değerler olmadığı için H8 hipotezi red edilmektedir. Taraftarların takımla özdeşleşme düzeyleri, satın alma niyeti düzeylerini doğrudan olumlu yönde etkilediği belirlenmiştir. Bu etki $(\beta=, 146$ ve $p<0,041)$ değerlerine göre istatistiki olarak anlamlı ve kabul edilebilir değerler olduğu için H9 hipotezi kabul edilmektedir.

Taraftarların takım sadakati düzeyleri, satın alma niyeti düzeylerini doğrudan olumlu yönde etkilediği belirlenmiştir. Bu etki $(\beta=, 580$ ve $p<0,000)$ değerlerine göre istatistiki olarak anlamlı ve kabul edilebilir değerler olduğu için H10 hipotezi kabul edilmektedir.

\subsection{YEM 'de Değişkenlerin Aracılık Etkilerine Ait Bulgular}

YEM'de bağımlı ve bağımsız değişkenlerin tanımlanması diğer istatistiki yöntemlere göre farklıdır. Çünkü YEM' de bir değişken, hem bağımlı değişken hem de bağımsız değişken şeklinde araştırma modelinde 
bulunabilmektedir (Meydan ve Şeşen, 2015: 35). Bu nedenle, değişkenler arasında doğrudan ve dolaylı ilişkiler ve etkileşimler olabilmektedir.

YEM' de bağımlı değişkenler üzerinde doğrudan etkisi olmayan bağımsız değişkenlerin, diğer bağımlı değişkenler aracılığı ile de etkisi olması durumu aracılık etkisi olarak tanımlanmaktadır. Aracılık etkisi, iki değişken arasındaki ilişkiye üçüncü bir değişkenin aracılık etmesi olarak da tanımlanmaktadır (Şimşek, 2007, s. 22; Meydan ve Şeşen, 2015, s. 35). Diğer bir tanımda aracı değişken, iki değişken arasındaki ilişkinin nasıl ve neden meydana geldiğinin anlaşılmasına yardımcı olan değişken olarak ifade edilmektedir (Gürbüz, 2019: 106).

Araştırma modelinde yer alan kulüp imajı, marka efangelizmi ve takımla özdeşleşme değişkenleri, etkileyen/bağımsız değişken iken, satın alma niyeti değişkeni, etkilenen/bağımlı değişken olarak tanımlanmıştır. Takın sadakati değişkeni ise hem etkileyen değişken hem de etkilenen değişken olduğu için aracı değişken olarak model de yer almaktadır. Modelde yer alan değişkenler arasındaki dolaylı etkilere bakıldığında ise, kulüp imajı, marka efangelizmi ve takımla özdeşleşmenin, taraftarların satın alma niyetine etkisinde takım sadakatinin aracılık rolüne sahip olduğu varsayılmaktadır.

Baron ve Kenny (1986)’ e göre YEM ‘de bir modelde yer alan değişkenlerin aracılık etkilerinin incelenebilmesi için;

(1) Bağımsız/Etkileyen değişkenin (kulüp imajı, marka efangelizmi ve takımla özdeşleşme), bağımlı değişken (satın alma niyeti) üzerinde istatistiksel olarak anlamlı bir etkisi olmalıdır.

(2) Bağımsız/Etkileyen değişkenin, Aracı(moderatör) değişken (Takın sadakati) üzerinde istatistiksel olarak anlamlı bir etkisi olmalıdır.

(3) Aracı(moderatör) değişkenin, bağımlı/etkilenen değişken üzerinde istatistiksel olarak anlamlı bir etkisi olmalıdır.

(4) Aracı(moderatör) değişken modele eklendiğinde, bağımsız/etkileyen değişkenin, bağımlı/etkilenen değişken üzerindeki etkisi düşerken, aracı(moderatör) değişkenin de bağımlı/etkilene değişken üzerinde istatistiksel olarak anlamlı bir etkisi olmalıdır. (Baron ve Kenny, 1986; Meydan ve Şeşen, 2015: 130). Aracı(moderatör) değişken, bağımlı/etkilenen değişken ile birlikte analize dahil edildiğinde; aracı(moderatör) değişken, bağımlı/etkilenen değişkeni anlamlı olarak etkilemelidir. Bu durumda bağımsız/etkileyen değişken ile bağımlı/etkilenen değişken arasındaki ilişki anlamsız çıkarsa "tam aracılık etkisi", bağımsız/etkileyen değişken ile bağımlı/etkilenen değişken arasındaki ilişkide azalma olursa "kısmi aracılık etkisinden" söz edilmektedir (Gürbüz,2019: 106).

Tablo 6: Değişkenler Arası Standardize Edilmiş Doğrudan Etkiler

\begin{tabular}{|l|lllll|}
\hline & $\begin{array}{l}\text { Takımla } \\
\text { Özdeşleşme }\end{array}$ & $\begin{array}{l}\text { Marka } \\
\text { Efangalizmi }\end{array}$ & $\begin{array}{l}\text { Kulüp } \\
\text { İmajı }\end{array}$ & $\begin{array}{l}\text { Takım } \\
\text { sadakati }\end{array}$ & $\begin{array}{l}\text { Satın Alma } \\
\text { Niyeti }\end{array}$ \\
\hline Takım Sadakati &, 000 &, 603 &, 361 &, 000 &, 000 \\
Satın Alma Niyeti &, 146 &, 213 &, 000 &, 580 &, 000 \\
\hline
\end{tabular}

Tablo 6' da araştırma modelinde yer alan değişkenler arası standardize edilmiş doğrudan etkilere ait değerlere bakılmaktadır. Buna göre, Hipotez 11 için; Kulüp imajının(bağımsız değişken), taraftarların satın alma niyetine(bağımlı değişken) etkisinin $(\beta=, 000$ ve $p<0,252)$ olduğu görülmektedir. Bu durumda kulüp imajının, taraftarların satın alma niyeti doğrudan etkisi bulunmadığından birinci koşul sağlanamamaktadır. Bu nedenle takım sadakatinin aracılık etkisinden de söz edilemediğinden H11red edilmiştir.

Hipotez 13 için; Taraftarların takımla özdeşleşme düzeylerinin satın alma niyetine etkisinin $(\beta=, 146$ ve $p<0,041)$ olduğu görülmektedir. Bu durumda aracılık etkisinin ölçülmesinde birinci koşul sağlanmıştır. İkinci koşulda takımla özdeşleşme düzeyinin takım sadakati (aracı değişkene) düzeyine doğrudan etkisinin $(\beta=, 000$ ve $\mathrm{p}<0$,227) olmadığı görülmektedir. ikinci koşul sağlanamadığından aracılık etkisinden söze dilememektedir. Bu nedenle $\mathrm{H} 13$ red edilmiştir.

Hipotez 12 için; Taraftarların marka efangelizm algılarının, satın alma niyetine etkisinin $(\beta=, 213$ ve p <0,042)olduğu görülmektedir.Bu durumda aracılık etkisinin ölçülmesinde birinci koşul sağlanmıştır İkinci koşulda taraftarların marka efangelizm düzeylerinin(bağımsız değişken), taraftarların takım sadakati (aracı 


\section{Ş. Altın - L. Bezgin Ediş - İ. Tüfekci - B. Altın 12/4 (2020) 3759-3775}

değişken) düzeyine etkisinin $(\beta=, 603$ ve $p<0,000)$ olduğu görülmektedir. Bu durumda ikinci koşul sağlanmıştır. Ü̧̧̈ıü koşulda, taraftarların takım sadakati (aracı değişken) düzeyinin, taraftarların satın alma niyetine (bağımlı değişken) etkisinin $(\beta=, 580$ ve $p<0,000)$ olduğu görülmektedir. Bu durumda üçüncü koşul sağlanmıştır. Bu durumda aracılık etkisinin ölçülmesinde H12 için birinci, ikinci ve üçüncü koşullar sağlanmıştır. Dördüncü koşulun test edilebilmesi için Tablo 5 ve Tablo 6 birlikte yorumlanmalıdır.

Tablo 7: Değişkenler Arası Standardize Edilmiş Toplam Etkiler

\begin{tabular}{|l|lllll|}
\hline & $\begin{array}{l}\text { Takımla } \\
\text { Özdeşleşme }\end{array}$ & $\begin{array}{l}\text { Marka } \\
\text { Efangalizmi }\end{array}$ & $\begin{array}{l}\text { Kulüp } \\
\text { İmaji }\end{array}$ & $\begin{array}{l}\text { Takım } \\
\text { sadakati }\end{array}$ & $\begin{array}{l}\text { Satın Alma } \\
\text { Niyeti }\end{array}$ \\
\hline Takım sadakati &, 000 &, 603 &, 361 &, 000 &, 000 \\
Satın Alma Niyeti &, 146 &, 562 &, 209 &, 580 &, 000 \\
\hline
\end{tabular}

Tablo $6^{\prime}$ da ki değerlere bakıldığında, taraftarların marka efangelizm algılarının, satın alma niyetine doğrudan etkisinin $(\beta=, 213$ ve $p<0,042)$ olduğu görülmektedir. Tablo 7'ye göre taraftarların marka efangelizm algılarının, satın alma niyetine toplam etkisinin $(\beta=, 562 p<, 005)^{\prime}$ dir. Beta $(\beta)$ regresyon katsayının, $\beta=, 562$ 'den $\beta=, 213^{\prime} \mathrm{e}$ düşmüştür. Bunun nedeni, aracı değişken olan takım sadakatinin modele dâhil edilmesidir. Ayrıca taraftarların takım sadakati düzeylerinin, satın alma niyetine etkisinin $(\beta=, 580$ ve $p<0,000)$ olduğu görülmektedir. Bu sonuçlara göre aracılık etkisinde dördüncü koşul sağlanmaktadır. Elde edilen bu bulgulara göre H12 hipotezi kabul edilmiştir. Yani taraftarların marka efangelizm algılarının, satın alma niyeti değişkeni üzerindeki etkisinde takım sadakati değişkenin "kısmi aracılık etkisi" vardır.

\section{SONUÇ VE TARTIŞMA}

Araştırma sonuçlarına göre kulüplerin sahip olduğu kulüp imajının, taraftarların takım sadakati düzeyini olumlu yönde ve doğrudan etkilediği görülmektedir. Bu sonuç, davranışsal sadakatin en etkili boyutunun kulüp ürünlerine olan sadakatin olduğu (Giray ve Girişken, 2015), sonucuyla benzerlik gösterse de doğrudan takım sadakatini etkilemesi yönüyle özgünlük taşımaktadır. Ayrıca kulüp imajının, taraftarların satın alma niyetini olumlu yönde ve doğrudan etkilediği görülmektedir. Ancak bu etkinin istatiksel olarak anlamlı bir etki olmadığı görülmüştür. Bu durumda kulüp imajının olumlu yönde artırılması durumunda taraftarların takım sadakatinin artması ve lisanslı ürünleri satın alma niyetinin olumlu yönde etkilenmesi beklenmektedir.

Taraftarların marka efangelizm algıları ile kulüp imajı, takım sadakati, satın alma niyeti ve takımla özdeşleme düzeyleri arasında olumlu yönde güçlü bir ilişki olduğu görülmektedir. Bu sonuç, marka efangelizmi üzerinde marka güveni ve marka özdeşleşmesinin etkisinin olduğu (Yapraklı vd., 2020) sonucuyla ve etkili bir kulüp imajının bilet satışları ve taraftarların memnuniyet düzeyleri üzerinde olumlu etkilere sahip olduğu (Beccarini ve Ferrand, 2006), Göktaş ve Tarakçı (2020) marka efangelizminin satın alma niyeti üzerinde etkisinin belirlendiği araştırmalarla benzerlik göstermektedir. Ancak marka efangelizm algısının kulüp imajına, takım sadakatine ve takımla özdeşleme düzeylerine etkileri açısından özgünlük taşımaktadır. Başka bir araştırmada spor kulüplerinin toplum yararına faaliyetlerde bulunmasının ve basın ve medya araçlarında sürekli yer almasının kurumsal imajı artırdığı belirtilmektedir (Kargün vd., 2017). Bu durumda güçlü bir kulüp imajına sahip olmanın taraftarların marka efangelizm algısını, takım sadakatini, satın alma niyetini ve takımla özdeşleşme düzeyini artırması beklenmektedir. Diğer bir araştırmada, takımla özdeşleşen taraftarların kulübün amblemlerini veya renklerini taşıyan kıyafetleri tercih ettiği belirtilmekte, takım özdeşleşmeleri yüksek olan taraflar kendilerini kulübe bağlı hissettiklerini ifade etmekte ve takımları için daha fazla zaman ve kaynak ayırdığı belirtilmektedir (Sutton vd., 1997; Shapiro vd., 2013). Bu sonuçlar da taraftarların takımla özdeşleşme düzeyleri ile kulüplerin sahip olduğu kulüp imajları ve satın alma niyeti arasında olumlu yönde güçlü ilişki olduğu sonucunu desteklemektedir.

Araştırmadan elde edilen diğer bir sonuca göre, taraftarların takımla özdeşleşme düzeylerinin, takım sadakati düzeyini olumlu yönde ve doğrudan etkilediği bilinmektedir. Ayrıca taraftarların, satın alma niyeti düzeylerini olumlu yönde ve doğrudan etkilediği görülmektedir. Bu sonuçlar, taraftarların takımla özdeşleme düzeylerinin kulübünün etkinliklerine katılma isteklerini (Fisher ve Wakefield, 1998; Aycan vd., 2009), takımların ürünlerini satın alma (Gwınner ve Swanson, 2003; Harolle vd., 2010), lisanslı ürünlere yönelik alım yapma (Wann ve Branscombe, 1993), sponsorların ürünlerini satın alma niyetine (Madrigal, 2001; Gwınner ve Swanson, 2003) etkilerine ilişkin sonuçlarla benzerlik taşımaktadır. Torlak vd. (2014) yaptı̆̆ı araştırmada; taraftarların tuttukları takımın lisanslı ürünlerini satın alma niyetleri üzerinde, takımlar ile özdeşleşme 


\section{Ş. Altın - L. Bezgin Ediş - İ. Tüfekci - B. Altın 12/4 (2020) 3759-3775}

düzeylerinin, etkili olduğunu tespit etmiştir. Bu durumda, taraftarların takımla özdeşleşme düzeyi arttırıldıkça takım sadakati ve lisanslı ürünleri satın alma isteklerinin de artması beklenmektedir.

Aracılık etkisine ilişkin sonuçlara bakıldığında ise, kulüp imajının, taraftarların satın alma niyetine üzerinde anlamlı etkisi olmadığı için takım sadakatinin aracılık etkisinden de söz edilememektedir. Aynı zamanda takımla özdeşleşme düzeyinin takım sadakati üzerinde doğrudan etkisi olmadığı için aracılık etkisinden söz edilememektedir. Taraftarların marka efangelizm algılarının, satın alma niyeti değişkeni üzerindeki etkisinde takım sadakati değişkenin "kısmi aracılık etkisi" vardır. Bu aracılık etkisine ilişkin literatürde pek çalışma olmamasından dolayı araştırma bu yönüyle de özgünlük taşımaktadır.

Genel olarak, kulüplerin sahip olduğu kulüp imajının artırılması durumunda taraftarların takımlarına duydukları sadakatin de artacağı söylenebilir. Kulüp imajının artırılması taraftarların takımlarına yönelik marka efangelizm algılarının da olumlu yönde artıracağı, bu durumun aynı zamanda taraftarlarının kendilerini takımlarıyla özdeşleştirme düzeylerini de arttıracağı ön görülmektedir. Bununla birlikte taraftarların marka efangelizm algılarının yüksek olması durumda, taraftarların takımlarına duyduğu sadakatin ve kulübün ürünlerine yönelik satın alma niyetinin ve taraftarların kendilerini takımla özdeşleştirme düzeylerinin de yüksek olması beklenmektedir. Bu durumda kulüplerin taraftarların marka efangelizm algılarını artıracak faaliyetlere yönelmeleri önerilmektedir. Taraftarlarının kendilerini takımlarıyla özdeşleştirme düzeyleri arttıkça taraftarların takımlarına duyduğu sadakatin ve kulübün ürünlerine yönelik satın alma niyetinin de arttıracaktır. Yani diğer bir değişle; spor kulüpleri lisanslı ürünlerinin daha fazla talep görmesini istiyorsa daha taraftarla özdeşleşmesi ve taraftarılya olan bağını daha da güçlendirerek güçlü bir savunucusu (efangelizm) haline getirmesi gerekmektedir. Aynı zamanda taraftarların takım sadakati ne kadar artarsa lisanslı ürün satın alma niyetleri de aynı oranda artmaktadır.

$\mathrm{Bu}$ araştırmanın sonuçları araştırmanın uygulandığı taraftarlarla sınırlıdır ve araştırma farklı örneklem gruplarında farklı sonuçlar yaratabileceği düşünülmektedir. Bununla birlikte marka efangelizmi, kulüp imajı, takım sadakati, takımla özdeşleşme ve satın alma niyeti değişkenlerinin daha farklı değişkenlerle incelenmesi spor kulüpleri, işletmeler ve spor endüstrisi açısından oldukça faydalı olacağı düşünülmektedir.

\section{KAYNAKÇA}

Altınok, B., Ekinci, N. E., Çimen, K., Özdilek, Ç., ve Kaya, İ. (2017). Lise öğrencilerinin taraftarı oldukları takım ile özdeşleşme düzeylerinin incelenmesi. Spor Ĕ̆itim Dergisi, 1(1), 59-68.

Anggraini, L. (2018). Understanding brand evangelism and the dimensions involved in a consumer becoming brand evangelist. Sriwijaya International Journal of DynamicEconomics and Business, 2(1), 63-84.

Ashforth, B. E., and Mael, F. (1989). Social 1dentity theory and the organization,. Academy of Management Review, 14(1), 20-39.

Aycan, A., Polat, E., ve Uçan, Y. (2009). Takım özdeşleşme düzeyi ile profesyonel futbol müsabakalarına seyirci olarak kararını etkileyen değişkenler arasındaki ilişkinin incelenmesi. Spormetre Beden Eğitimi ve Spor Bilimleri Dergisi, 7(4),169-174.

Ayhan, B., Aktaş , H., ve Çelik , F. (2017). Lisanslı taraftar ürünlerinin kullanım motivasyonları: Üniversite öğrencileri üzerine bir araştırma. Gümüşhane Üniversitesi İletişim Fakültesi Elektronik Dergisi , 5(2), 549572.

Balıkçığlu, B., Oflazoğlu, S. (2015). Marka evangelizmi, benlik-marka imajı uyumu ve marka sadakati ilişkisi üzerine ampirik bir araştırma. Taraftar Ve Tüketim Araştırmaları Dergisi, 7 (2), 19-45.

Baron, R. M. and Kenny, D. A. (1986). The Moderator-Mediator Variable Distinction İn Social Psychological Research: Conceptual, Strategic and Statistical Considerations. Journal of Personalityand Social Psychology, 51 (6), 1173-1182.

Bayram, N., (2010). Yapısal Eşitlik Modellemesine Giriş- AMOS Uygulamaları, İstanbul, Ezgi Kitapevi.

Bauer, H.H., Stokburger-Sauer, N.E., and Exler, S. (2008). Brand image and fan loyalty in professional sportteam: a refined model and empirical assessment. Journal of Sport Management, 22(2), 205-226. 


\section{Ş. Altın - L. Bezgin Ediş - İ. Tüfekci - B. Altın 12/4 (2020) 3759-3775}

Bee, C.C., and Havitz, M.E. (2010). Exploring the relationship between involvement, fan attraction, psychological commitment and behevioural intentions in a sports spectator context. International Journal of Sports Marketing ESponsorship, 11(2), 140-157.

Beccarini , C., and Ferrand , A. (2006). Factors affecting soccer club season ticket holders' satisfaction: the influence of club image and fans' motives. European Sport Management Quarterly,6(1), 1-22.

Bodet, G., and Bernache-Assollant, I. (2011). Consumer loyalty in sport spectatorship services: the relationships with consumer satisfaction and team identification. Psychology and Marketing, 28(8), 781802.

Bromberger, C., Hayot, A., and Mariottini, J.M. (1987). Allerl'om! forzajuve! la passionpour le soccer a' marseille et a turin, [come on om! forzajuve! the passion for soccer in marseilles and in turin]terrain. Carnetdu Patrimoine Ethnologique, 8(1), 8-41.

Büyükakgül, Ü. C. ve S. G. Engin, (2017). Spor taraftarlarının yeni sadakat anlayışı: efangelizm. Ed. Kurtuldu, H.S., 22. Pazarlama Kongresi, 28,29,30 Eylül 2017, Trabzon.

Carlson, B. D., D. T., Donavan, Kevin J., and Cumiskey, (2009). Consumer-brand relationships in sport: brand personality and identification. International Journal of Retail \& Disribution Management, 37(4), 370-384.

Cialdini , R.,Borden, R., Thorne , A., Walker, M., and Sloan, L. (1976 ). Basking in reflected glory: three (football) field studies. Journal of Personality and Social Psychology, 34(3),366-373.

Çağlar, İ. (2003). Örgüt Geliştirme, Ankara, Nobel Yayıncılık.

Çelik, M., Ünal , H., ve Aksu , A. (2019). Göztepe spor kulübü taraftarlarının kulüp ürünlerini satın alma davranışları üzerine bir araştırma, Uluslararası Sosyal Araştırmalar Dergisi , 12(68),1400-1407

Çiftyıldız, S. S. (2015). Takımların Lisanslı Ürünleri Bağlamında, Takımla Özdeşleşme, Duygusal Marka Bağlılığı Ve Satın Alma Niyeti Olguları Arasındaki İlişkileri İncelemeye Yönelik Bir Uygulama. Electronic Journal Of Social Sciences, 14(53), 232-241.

Demirel, M., Karahan Güven, B., ve Ünlü, H. (2007). Farklı üniversitelerdeki spor taraftarlarının takımları ile özdeşleşme düzeyleri, Nĭğde Üniversitesi Beden Eğitimi ve Spor Bilimleri Dergisi, 1(2), 76-86.

Dwyer, B.,Greenhalgh, G. P., and Le Crom, C. W. (2015). Exploring fan behavior: developing a scaleto measure sport efangelism, Journal of Sport Management, 29(6), 642-656.

Doss, S. K., and Carstens, D. S. (2014). Big five personality traits and brand evangelism, International Journal of Marketing Studies, 6(3), 13.

Enginkaya, E. (2014). Futbol taraftarlarının sponsor markalara ilişkin tutum, satın alma niyeti ve takımla özdeşleşmeleri arasındaki ilişki, Marmara Üniversitesi İktisadi ve İdari Bilimler Dergisi, 36(2), 145-158.

Fisher, R. J., and Wakefield, K. (1998), Factors leading to group 1dentification: A field study of winners and losers. Psychology and Marketing, 15(1), 23-40.

Fişek, K. (1985). 100 Soruda Türkiye Spor Tarihi, İstanbul, Gerçek Yayınevi.

Funk, D.C., and James, J. (2001). The psychological continuum model: A conceptual framework for understanding and individual's psychological connection to sport, Sport Management Review, 4(1), 119150.

Giray, C., ve Girişken , Y. (2015). Taraftar motivasyon faktörlerinin davranışsal sadakat üzerindeki etkisi: Fenerbahçe spor kulübü örneği, Ekonomik ve Sosyal Araştırmalar Dergisi, 11(2), 119-137.

Göktaş, B., Erdoğan Tarakçı, İ. (2020). Marka evangelizminin satın alma bağımlılığı, satın alma niyeti ve tavsiyede bulunma üzerindeki etkisi: taraftar ürünleri örneği. İşletme Araştırmaları Dergisi, 12 (1), 126145.

Günay, N., ve Tiryaki, Ş. (2003). Spor taraftarı özdeşleşme ölçeğinin (STÖÖ) geçerlik ve güvenirlik çalışması. Spor Bilimleri Dergisi, 14(1), 14-26.

Gürbüz, S. (2019), AMOS İle Yapısal Eşitlik Modellemesi, Ankara, Seçkin Yayıncılık. 


\section{Ş. Altın - L. Bezgin Ediş - İ. Tüfekci - B. Altın 12/4 (2020) 3759-3775}

Gwinner, K. and Swanson S. R. (2003). A model of fan 1dentification: antecedents and sponsorship outcomes, Journal of Services Marketing, 17,(3), 275-294.

Hair, J. F., Black W. C., Babin B. J., Anderson, R.E. (2010). Multivariate Data Analysis. Seventh Edition, Copyright By Pearson Prentice Hall, All Rights Reserve

Harolle, M., Trail G., Rodrigez A., and, Jordan J., (2010). Conative loyalty of latino non-latino prefessional baseball fans, Journal of Sport Management, 24(4), 456-471

Jensen, A.J., Wakefield, L., Cobbs, J. B., and Turner, B. A. (2015). Forecasting sponsorship costs: marketing intelligence in the athletic apparel industry, Marketing Intelligence \& Planning, 34(2), 281-298.

Jung, C. W. (2012). The influence of professional sports team's corporate social responsibility (csr) on team image, team identification, and team loyalty, Doctoral Dissertation. Thomas University, Florida, UMI Number: 3546650,

Kalaycı, Şeref. (2009), SPSS Uygulamah Çok Değişkenli İstatistik Teknikleri, Ankara, Asil Yayın.

Kargün, M., Dalkılıç, M., Ağaoğlu, Y. S., ve Kızar, O. (2017). Spor kulüplerine yönelik kurumsal imaj algısının araştırılması. Gaziantep Üniversitesi Spor Bilimleri Dergisi, 2(1), 62-73.

Katlav , T., ve Öney , E. (2018). Türkiye'deki taraftarların spor kulüplerindeki lisanslı ürünlere ilişkin satın alma niyetinin planlanmış davranış teorisine göre incelenmesi, International Journal of Cultural and Social Studies, 4(1),139-162 .

Kwak, D. H., Kwon, Y., and Lim, C. (2015). Licensing a sportsbrand: effects of teambrandcue, identification, and performance priming on multi dimensional values and purchase intentions. Journal of Product EBrand Management, 24(1), 2-40.

Küçükibiş, H. F., ve Yurtsızoğlu, Z. (2019). Investigation of the evangelism of sport team's attitudes of the high school students, Journal of Educationand Training Studies, 7(3), 106-113.

Laverie, D. A., and Arnett, D. B. (2000). Factor saffecting fan attendance: the influence of identity salience and satisfaction. Journal of Leisure Research, 3(2), 225-247.

Madrigal, R. (2001). Social identity effects in a belief-attitude-intentions hierarchy: implications for corporate sponsorship, Psychology \& Marketing, 18(2), 145-165.

Matzler, K.,Pichler, E. A., Hemetsberger, A. (2007). Who is spreading the word? the positive influence of extraversion on consumer passion and brand evangelism, American Marketing Association, Winter, $18(1), 25-32$.

Meydan, C. H. ve Şeşen H. (2015), Yapısal Eşitlik Modellemesi-Amos Uygulamaları, İkinci Baskı, İstanbul, Detay Yayıncilik.

Oliver, R. L., and Bearden, W. O. (1983). The role of involvement in satisfaction processes, ACR North American Advances, 10(1), 250-255.

Papadimitriou D. and Apostolopoulou, A. (2015). Capturing the meanings of sport licensed products. Journal of Marketing Communications. 24 (5),433-449.

Wilkie, W.L. (1994). Consumer Behavior. New York: John Wiley and Sons.

Pitts, B. G., Fielding L. W. and Miller, L. K. (1994). Industry segmentation theory and the sport industry: developing a sport industry segment model, Sport Marketing Quarterly, 3(1), 15-24.

Polat, E., Sönmezoğlu, U., Yıldız, K., ve Çoknaz, D. (2019). Futbol taraftarlarının takım imajı, takım sadakati ve takımla özdeşleşme düzeylerinin belirlenmesi. Uluslararası Spor Egzersiz ve Antrenman Bilimi Dergisi, 5(3), 143-153.

Riorini, S. V., and Widayati, C. C. (2016). Brand relationship and it seffect towards brand evangelism to banking service, International ResearchJournal of Business Studies, 8(1), 33-45.

Schumacker, R. E. and Lomax, R. G. (2010). A Beginner's Guide To Structural Equation Modeling. Third Edition. New York, by Taylor and Francis Group, LLC. 


\section{Ş. Altın - L. Bezgin Ediş - İ. Tüfekci - B. Altın 12/4 (2020) 3759-3775}

Shank, M.,D., (2002). Sports Marketing: A Strategic Perspective. New Jersey: PrenticeHall.

Şahin H., M., (2004). Beden Eğitimi ve Sporda Temel Kavramlar Sözlü̆̆̈̈̈, 2. Baskı, Ankara, Nobel Yayın Dağıtım,

Shapiro, S. L., Ridinger, L. L., and Trail, G. T. (2013). An analysis of multiple spectator consumption behaviors, identification, and future behavioral intentions with in thec ontext of a new college football program, Journal of Sport Management, 27(2), 130-145.

Sutton, W. A., Mc Donald, M. A., Milne, G. R., and Cimperman, J. (1997). Creating and fostering fan identification in professional sports. Sport Marketing Quarterly, 6(1), 15-22.

Şimşek, Ö. F. (2007). Yapısal Eşitlik Modellemesine Giriş-Temel İlkeler ve Lisrel Uygulamaları, Ankara, Ekinoks.

Tabachnick, B. G., and Fidell, L. S. (2012). Using Multivariate Statistics. SixthEdition, Copyright By Pearson Education, Inc, All Rights Reserved, Manufactured in the United States of America.

Torlak, Ö., Özkara, B. Y., ve Doğan, V. (2014). Taraftarların takımlarla özdeşleşme düzeylerinin, takımların lisanslı ürünlerine yönelik kalite algısı ve satın alma niyetine etkisi, Ege Akademik Bakı̧̧, 14(1), 73-81

Wann, D. L.,ve Branscombe, N. R. (1993). Sports fans: measuring degree of identification with their team, International Journal of Sport Psychology, 24(1), 1-17.

Yapraklı, T. Ş. ve Keser, E. ve Ünalan, M. (2020). Marka güveni ve marka özdeşleşmesinin marka evangelizmi üzerindeki etkisi. Uluslararası İktisadi ve İdari İncelemeler Dergisi, 27(1), 35-54

Yaşar, O. M. ve Turgut, M. (2019). E-fangelism of turkısh football supporters. Sportif Bakış: Spor ve Ĕğitim Bilimleri Dergisi, 6 (1), 353-366.

Yüksekbilgili, Z. (2018). Sport efangelism demographics. International Journal of Advanced Multidisciplinary Research and Review (IJAMRR), 6(9), 40-46.

Yüksekbilgili, Z. (2017). Spor takımı evangelizmi (efangelizm) ölçeğinin Türkçe'ye uyarlanması: güvenirlik ve geçerlilik çalışması, Yönetim ve Ekonomi: Celal Bayar Üniversitesi İktisadi ve İdari Bilimler Fakültesi Dergisi, 24(3), 959-969.

Yıldız, S. M. (2010). Spor ve Fiziksel Etkinlik Hizmetleri Pazarlaması, Ankara, Detay Yayıncilık.

Yılmaz, A. Ö. Ve Aykaç S. (2018). Marka imajının marka evangelizmine etkisinde marka güveninin ve marka sadakatinin aracı rolü. Uluslararası Hakemli Ekonomi Yönetimi Araştırmaları Dergisi 16(1), 53-75. 